\title{
Perencanaan Strategi Sistem Informasi Pada BKDIKLATDA Kota Salatiga Metode Ward And Peppart
}

\author{
Dina Sane Rissanti ${ }^{1}$, Yani Rahardja, S.E.,M.M. ${ }^{2}$, Penidas Fiodinggo Tanaem, S.Kom., \\ M.Cs. ${ }^{3}$ \\ ${ }^{1,2}$ Universitas Kristen Satya Wacana; Jl. Dr. O. Notohamidjojo No.1, Salatiga 50715, telp/fax of \\ (0298) 321212 \\ ${ }^{3}$ Program Studi Sistem Informasi, FTI UKSW, Salatiga \\ e-mail: *1682017102@student.uksw.edu, ${ }^{2}$ Yani.rahardja@uksw.edu. , \\ ${ }^{3}$ Penidas.fiodinggo@uksw.edu.
}

\begin{abstract}
Abstrak
BKDIKLATDA (Badan Kepegawain Diklat Daerah) kota Salatiga merupakan salah satu organisasi non profit yang bergerak di bidang kepegawaian, penunjang pendidikan dan urusan pelatihan pemerintahan. Adanya teknologi sistem informasi beserta pengembangan SI/TI sangat berpengaruh terhadap kesuksesan visi dan misi pada organisasi serta membantu proses bisnis di dalam organisasi sehingga sangat dibutuhkan perencanaan yang baik dan terstruktur. Untuk pengumpulan data dan informasi menggunakan metode ward and peppart dengan tools analisis SWOT, value chain, dan aplikasi portofolio dengan memakai pendekatan McFarlan Strategic Grid serta usulan sistem informasi. Pada penelitian ini menghasilkan usulan perencanaan strategi SI/TI berupa usulan web aplikasi pada BKDIKLATDA kota Salatiga. Dimana aplikasi ini nantinya dapat meningkatkan kinerja lebih efektif dan efisien. Serta dapat mempermudah proses kerja di dalam BKDIKLATDA kota Salatiga.
\end{abstract}

Kata kunci - analisis SWOT , Mc Farlan, Value Chain, Ward and Peppart

\begin{abstract}
BKDIKLATDA (Regional Education and Training Personnel Agency) Salatiga is a nonprofit organization engaged in personnel, education support and government training matters. The existence of information system technology along with IS/IT development is very influential on the success of the vision and mission of the organization as well as assisting business processes within the organization so that good and structured planning is needed. To collect data and information using the ward and peppart method with SWOT analysis tools, value chain, and portfolio applications using the McFarlan Strategic Grid approach and proposed information systems. In this study resulted in a proposed IS/IT strategic planning in the form of a proposed web application at the BKDIKLATDA Salatiga city. Where this application can later improve performance more effectively and efficiently. And can facilitate the work process in the BKDIKLATDA Salatiga city.
\end{abstract}

Keywords - SWOT analysis, Mc Farlan, Value Chain, Ward and Peppart

\section{PENDAHULUAN}

Berkembangnya teknologi informasi (TI) sangat diperlukan untuk semua organisasi sehingga perlu diterapkan teknologi informasi untuk membantu sebuah organisasi supaya lebih maju dan berkembang. Maka untuk meningkatkan sistem informasi dan teknologi informasi (SI/TI) dapat dilakukan dengan menyesuaikan SDM. Untuk penerapan SI/TI dalam organisasi terdapat 3 sasaran utama yaitu: pertama, memperbaiki efisiensi kerja, kedua, meningkatkan 
efektif menagement, ketiga, meningkatkan keunggulan kompetitif dalam organisasi [1]. Belum terstrukturnya sistem informasi dan teknologi informasi hanya memenuhi kebutuhan organisasi yang sifatnya semestara sehingga proses bisnis tidak berjalan dengan baik, maka sangat di perlukan perencanaan strategi sistem informasi supaya mendukung proses bisnisnya. Artian stategi ini yang akan di lakukan untuk waktu jangka panjang dan sifatnya sangat penting. Kerena perencanaan strategi sistem informasi menjadi lebih terarah, serta semua organisasi memerlukan perencanaan strategi sistem informasi [2]. Salah satunya instansi pemerintahan, supaya menunjang kualitas SI/TI serta meningkatkan nilai organisasi untuk terwujudnya visi misi organisasi digunakan strategi SI/TI.

BKDIKLATDA adalah instasi pemerintahan di lembaga kepegawaian kota Salatiga dan terletak di jalan pemuda No.1 kota Salatiga. Tugas utama dari BKDIKLATDA kota Salatiga yaitu melaksanakan fungsi kepegawaian, penunjang pendidikan dan pelatihan pemerintahan. BKDIKLATDA kota Salatiga mempunyai 3 bidang yaitu bidang sekretariat, pembinaan dan mutasi, beserta pengembangan dan diklat. BKDIKLATDA memliki visi: Pemerintahan good governance (program pemerintahan yang baik). good governance adalah program pemerintahan yang memiliki tujuan untuk meningkatkan efektivitas kebijakan otonomi daerah [3]. Dan misi meningkatkan sumber daya aparatur, wujudkan PNS (pegawai negeri sipil) dengan jabatan pada kompetensinya, meningkatkan pelayanan prima, meningkatkan pembinaan aparatur dan kesejahteraan PNSD (Pegawai Negeri Sipil Daerah).

Kegiatan di BKDIKLATDA kota Salatiga belum banyak menggunakan sistem informasi dan teknologi sistem informasi (SI/TI) untuk melakukan akvitas dalam organisasi supaya lebih efektif dan efisien. Pembangunan SI/TI tentunya sangat penting untuk organisasi salah satunya untuk pemeliharaan serta perasipan data. Dokumen berupa pelaporan dan pengadaan barang serta daftar hukuman displin, dan arsip berkas cuti beserta data data penting lainnya. Kurang efektinya pengelolaan data dapat berakibat fatal pihak pihak yang terkait. Pada permasalah tersebut karena masih minimnya penggunaan SI/TI. Untuk mengoptimalkan SI/TI pada BKDIKLATDA kota Salatiga maka di butuhkan perencanaan strategi sistem informasi.

Penelitian perencanaan strategi sistem informasi telah kerap dilakukan oleh beberapa peneliti sehingga dapat dijadikan referensi ataupun acuan untuk penyusunan penelitian studi kasus ini, sebagai berikut: Penelitian yang menggunakan pendekatan ward and peppart yang membahas perencanaan SI/TI di Dinas Perindustrian dan Tenaga Kerja Kota Salatiga. Pada penelitian ini melihat kondisi masalah yang belum maksimal menggunakan SI/TI menyebabkan data menjadi random, kemudian untuk proses bisnis banyak di lakukan secara manual serta belum adanya perencanaan strategi SI/TI guna mendukung proses bisnis di dispernaker [4].

Penelitian tentang perencanaan Strategi sistem informasi studi kasus di PT. Serasi Autoraya (trac) menggunakan metode ward and peppart. Hasil dari penelitian ini yaitu untuk mengembangan aplikasi sistem informasi layanan pelanggan, website trac, sistem informasi eksekutif, aplikasi SAP serta mengembangkan aplikasi sistem infromasi aset. Dengan tujuan memberikan kejelasan arah serta mendorong supaya lebih berkembang dari aspek SDM SI [5].

Penelitian tentang perencanaan Strategi sistem informasi studi kasus di BARENLIDBANGDA menggunakan metode ward and peppart menghasilkan sebuah perencanaan stategi sistem informasi yang memberikan masukan untuk mencapai visi misi pemerintah $e$ government di BARENLIDBANGDA [6].

Penelitian tentang perencanaan strategis sistem informasi dan teknologi informasi SI/TI pendidik dan tenaga kependidikan menggunakan metode ward aand peppart studi kasus di Disdikbudpora kota Metro. Dan menghasilkan sebuah blue print perencanaan strategis pada organisasi. Setelah memperoleh informasi melalui metode analisis yang di pakai dapat menghasilkan informasi yang terintegritas untuk kepentingan administrasi serta pelayanan publik. Strategi berorganisasi bertujuan untuk pelayanan prima dan dapat mencapai dengan

Rissanti, et., al [Perencanaan Strategi Sistem Informasi pada BKDIKLATDA Kota Salatiga Metode Ward and Peppart] 
penerapan peningkatan pengolahan data PTK yang optimal dengan di dukung TIK, peranan TIK yang optimal dapat ditingkatkan dengan penyediaan sarana dan prasarana pendidikan yang baik. Serta untuk peningkatan kualitas managemen pendidikannya dapat mengembangkan apliaksi TIK [7].

Mengacu pada penelitian terdahulu maka penelitian yang dilakukan saat ini bertujuan untuk menyusun rumusan perencanaan strategi sistem informasi di BKDIKLATDA kota Salatiga dengan menggunakan metode ward and peppart. Adapun metode yang digunakan ward and peppart yaitu analisis SWOT, analisis Value Chain, serta menggunakan metode Mc Farlan's Stragi Grid. Hasil dari penelitian ini berupa usulam sistem informasi arsip (SIARSIP), sistem informasi sarana dan prasarana (SISARPRAS), dan sistem informasi tanda tangan di gital (E-TTD) serta merekomendasikan sistem informasi absensi ke absensi mobile karena sering terjadinya kerusakan mesin absensi finger print sehingga dapat meminimalisir biaya untuk pembelian mesin absensi.

\section{METODE PENELITIAN}

\subsection{Kajian Pustaka}

\subsubsection{Strategi SI dan Strategi TI}

Strategi sistem informasi (SI) merupakan upaya suatu organisasi dalam mencapai strategi bisnis. Serta untuk meningkatkan kinerja suatu organisasi harus menerapkan teknologi.

Sedangkan untuk strategi TI yaitu mencakup pengelolaan teknologi yang dapat diterapkan karena dapat menunjang strategi SI yang sudah di tata [8].

\subsubsection{Perencanaan Strategis SI}

Perencanaan strategis sistem informasi merupakan laporan identifikasi portofolio guna mencapai tujuan bisnis pada organisasi. Mempelajari SI/TI berpengaruh pada kontribusi terhadap organisasi dan kinerja bisnis [9].

\subsection{Tahap Penelitian}

Dalam penelitian ini menggunakan metode pengumpulan data kualitatif, karena bersifat diskriptif serta menganalisa keadaan lingkungan di BKDIKLATDA kota Salatiga. Pada gambar 1 menggambarkan tahapan peenelitian yang nantinya dapat di ambil kesimpulan.

Rissanti, et., al [Perencanaan Strategi Sistem Informasi pada BKDIKLATDA Kota Salatiga Metode Ward and 


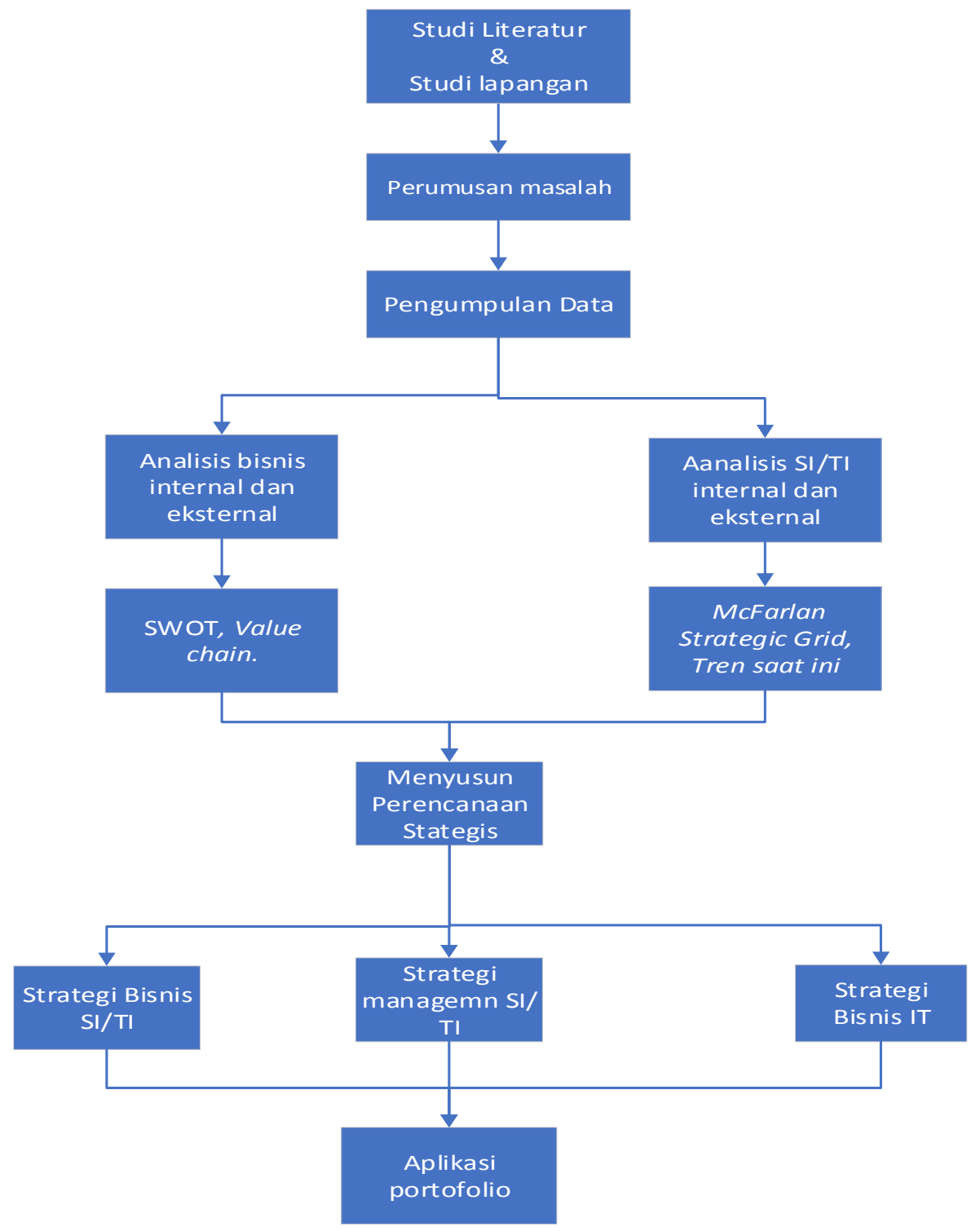

Gambar 1. Tahap Penelitian

Keterangan gambar 1:

1. Studi literatur dan studi lapangan

Pada studi literatur mencari referensi yang topiknya tentang penelitian yang akan di ambil sehingga dapat membantu untuk mengebangkan topik yang nantinya akan di bahas yaitu tetang metode ward and peppart untuk studi lapangan mengamati proses bisnis di BKDIKLATDA kota Salatiga.

2. Perumusan masalah

Setelah mengamati proses binis di BKDIKLATDA kota Salatiga dapat mendefinisikan masalah yang ditentukan untuk diangkat dalam penelitian.

3. Pengumpulan data

Temuan rumusan masalah, selanjutnya di lengkapi dengan data-data untuk dapat di analisis. Peneliti untuk pengumpulan data melakukan dengan wawancara kepada pihak yang

Rissanti, et., al [Perencanaan Strategi Sistem Informasi pada BKDIKLATDA Kota Salatiga Metode Ward and 
berwenang dan observasi dengan mengamati proses bisnis di BKDKLATDA kota Salatiga. Kemudian melakukan analisis data menggunakan pendekatan analisis value chain, analisis Strengths, Weakness, Opportunity, Thearts (SWOT), dan analisis lingkungan SI/TI internal maupun eksternal. Kemudian dapat mengatur perencanaan strategis yang di terapkan nanti.

4. Aplikasi portofolio

Untuk selanjutnya peneliti dapat menyusun aplikasi portofolio.

\subsection{Metode Ward and Peppart}

Pendekatan metode Ward and Peppard dimulai dari kondisi SI/TI yang kurang bermanfaat dimasa lalu pada sebuah organisasi dan di lanjutkan menangkap peluang bisnis beserta meningkatkan keunggulan yang kompetitif di suatu organisasi dikarenakan mampu memanfaatkan SI/TI dengan semaksimal mungkin.

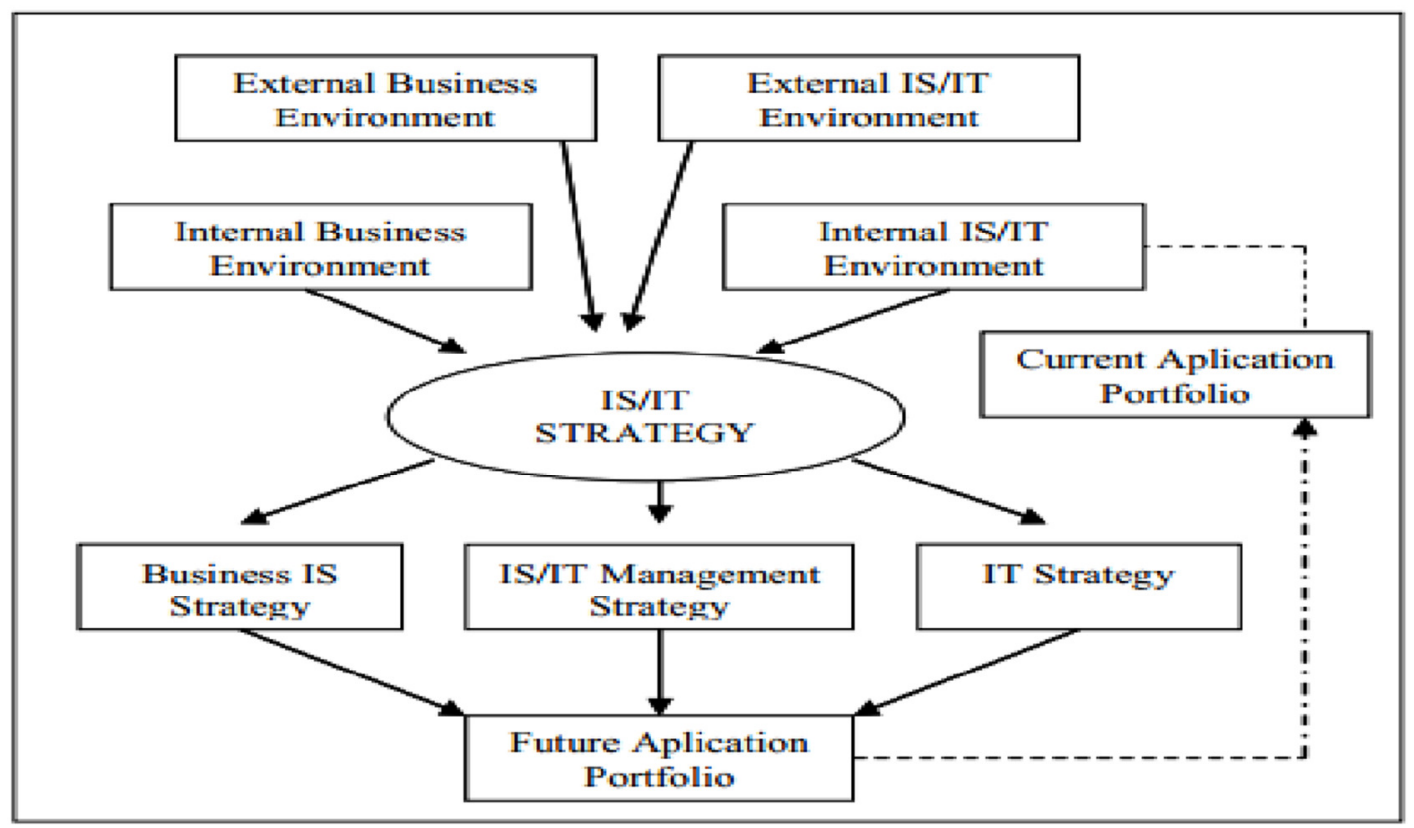

Gambar 2. Metodelogi Ward and Peppart [2]

Berikut penjelasan dari metodologi ward and peppat dan terdiri tahapan masukan (input) dan tahapan keluaran (output), dan di gambarkan dalam bentuk skema perencanaan strategi sistem informasi yang dapat dilihat pada gambar 2 sebegai berikut:

Tahapan masukan:

1. Analisis lingkungan bisnis internal, merupakan sejauh mana yang telah dilakukan oleh organisasi maupun perusahaan agar mencapai visi misi organisasi dan hal apa yang perlu untuk diperbaruhi maupun di kembangnya untuk meningkatkankan proses kerja di organisasi maupun perusahaan [10].

2. Analisis lingkungan bisnis eksternal terdiri dari aspek ekonomi, industri serta iklim yang bersaing organisasi maupun perusahaan [10].

3. Analisis lingkungan SI/TI internal, merupakan dari kondisi SI/TI organisasi yang ada untuk saat ini, bagaimana kematangannya, bagaimana kontribusi terhadap SDM, bagaimana insfrastruktur tekonologi bisnis serta portofolio SI/TI sekarang ini [10]. 
4. Analisis lingkungan SI/TI eksternal yaitu mencakup tren teknologi dan peluang, beserta penggunaan SI/TI oleh kompetitor, pelanggan dan pemasok [10].

Tahapan Keluaran:

1. Business IS Strategy, meliputi setiap unit maupun fungsi bisnis yang akan mengembangkan SI/TI untuk mencapai tujuannya, gambaran arsitektur informasi serta portofolio aplikasi

2. IT Strategy, meliputi kebijakan dan strategi bagi pengelolaan teknologi dan sumber daya manusia SI/TI.

3. IS/IT Management Strategy meliputi kebijakan umum yang di terapkan organisasi, untuk memastikan kebijakan SI/TI yang dibutuhkan menentukan strategi yang tepat pada kebutuhan organisasi sangat di butuhkan [11].

\section{PEMBAHASAN}

\subsection{Analisis Lingkungan Bisnis Internal dan Eksternal}

Pada tahap pertama menyusun analisis SWOT (Strength, Weakness, Opportunity, Threats) bertujuan untuk mengetahui kekuatan, kelemahan, peluang, beserta ancaman dilihat dari lingkungan bisnis internal dan lingkungan bisnis eksternal pada BKDIKLATDA kota Salatiga. Pada tabel 1 ini hasil dari analisis yang di lakukan.

Tabel 1. Analisis SWOT

\begin{tabular}{|c|c|c|}
\hline & Kekuatan (Strengths) & Kelemahan(Weakness) \\
\hline Eksternal & $\begin{array}{l}\text { 1. Memiliki web blog } \\
\text { 2. Sudah ada aplikasi yang di } \\
\text { kembang oleh } \\
\text { BKDIKLATDA yaitu } \\
\text { aplikasi Sie Cute, Simpeg, } \\
\text { Si absensi dan E-kinerja } \\
\text { 3. Pembuatan aplikasi sie } \\
\text { cute yang di buat dan di } \\
\text { kembangkan oleh } \\
\text { developer BKDIKLATDA }\end{array}$ & $\begin{array}{l}\text { 1. SDM dalam bidang IT } \\
\text { terbatas(pegawai tidak } \\
\text { mampu mengoprasikan } \\
\text { dan menyelesaikan } \\
\text { permasalahan yang terjadi } \\
\text { pada si cute) } \\
\text { 2. Jaringan internet kurang } \\
\text { stabil } \\
\text { 3. Belum adanya sistem } \\
\text { informasi } \\
\text { pengelolaan data arsip dan } \\
\text { sistem informasi sarana } \\
\text { dan prasarana }\end{array}$ \\
\hline Peluang (Opportunity) & Strategis $(\mathrm{S}-\mathrm{O})$ & Strategis (W-O) \\
\hline $\begin{array}{l}\text { 1. SDM yang berkulitas } \\
\text { dengan lulusan sesuai } \\
\text { dengan bidangnya. } \\
\text { 2. Berkembangan teknologi } \\
\text { informasi }\end{array}$ & $\begin{array}{l}\text { 1. Memanfaatkan blog dari } \\
\text { BKDIKLATDA untuk } \\
\text { menyebarluaskan } \\
\text { informasi } \\
\text { BKDIKLATDA. tentang } \\
\text { 2. Mengoptimalkan } \\
\text { penggunaan aplikasi yang } \\
\text { sudah ada } \\
\text { BKDIKLATDA } \\
\text { 3. Memperbaharui aplikasi } \\
\text { yang ada seperti SI Cute, } \\
\text { SIMPEG, SI Absensi, E- }\end{array}$ & $\begin{array}{l}\text { 1. Merecrut SDM baru yang } \\
\text { mempunyai keahlian } \\
\text { dalam bidangnya. } \\
\text { 2. Belum adanya pelatihan } \\
\text { untuk pengguna SI/TI pada } \\
\text { pegawai baru. } \\
\text { 3. Mengadakan pelatihan } \\
\text { SDM sesuai dengan } \\
\text { bidangnya untuk merekrut } \\
\text { SDM yang berkualitas. } \\
\text { 4. Mengembangkan sistem } \\
\text { pengelolaan arsip }\end{array}$ \\
\hline
\end{tabular}

Rissanti, et., al [Perencanaan Strategi Sistem Informasi pada BKDIKLATDA Kota Salatiga Metode Ward and Peppart] 


\begin{tabular}{|c|c|c|}
\hline & 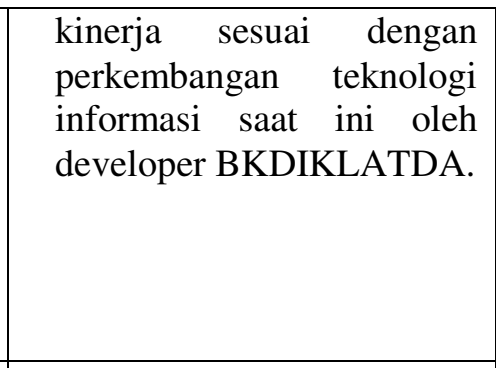 & $\begin{array}{l}\text { memanfaatkan teknologi } \\
\text { informasi yang } \\
\text { berkembang pesat saat ini. } \\
\text { 5. Mengimplementasikan } \\
\text { absensi secara paperless } \\
\text { atau terkomputerisasi } \\
\text { dengan memanfaatkan } \\
\text { SDM berkualitas yang ada. }\end{array}$ \\
\hline Ancaman (Thearts) & Strategis $(\mathrm{S}-\mathrm{T})$ & Strategis (W-T) \\
\hline $\begin{array}{l}\text { 1. Masih adanya pegawai } \\
\text { yang belum memahami } \\
\text { alur prosedur pengajuan } \\
\text { cuti dan penggunaan } \\
\text { sicute. } \\
\text { 2. Server down saat proses } \\
\text { kinerja. } \\
\text { 3. Peluang craking untuk } \\
\text { membobol pada sistem } \\
\text { sie cuti, dan e kinerja. }\end{array}$ & $\begin{array}{l}\text { 1. Mengotomatisasi proses } \\
\text { verifikasi berkas cuti. } \\
\text { 2. Memperbaiki pada } \\
\text { settingan DNS dan } \\
\text { melakukan maintenance } \\
\text { server } \\
\text { 3. Menambah kecepatan } \\
\text { internet atau mengganti } \\
\text { provider yang lebih bagus } \\
\text { 4. Melakukan pembaharuan } \\
\text { password } \\
\text { 5. Mengganti mesin absensi } \\
\text { dari fingerprint ke absensi } \\
\text { berbasis mobile }\end{array}$ & $\begin{array}{l}\text { 1. Memberikan pelatihan } \\
\text { pada bidang IT dan } \\
\text { perekrutan SDM pada } \\
\text { bidang IT } \\
\text { 2. Meningkatkan keamanan } \\
\text { pada aplikasi sie cute dan } \\
\text { e-kinerja serta melakukan } \\
\text { audit secara berkala. }\end{array}$ \\
\hline
\end{tabular}

\subsection{Analisis Value Chain}

Pada analisis ini melakukan pemetaan proses bisnis di BKDIKLATDA kota Salatiga. beserta melihat proses kerja di BKDIKLATDA kota Salatiga dan dapat di bagi dua yaiti aktifitas utama dan aktifitas pendukung. Gambar 3 penjelasan dari analisis Value Chain di BKDIKLATDA kota Salatiga.

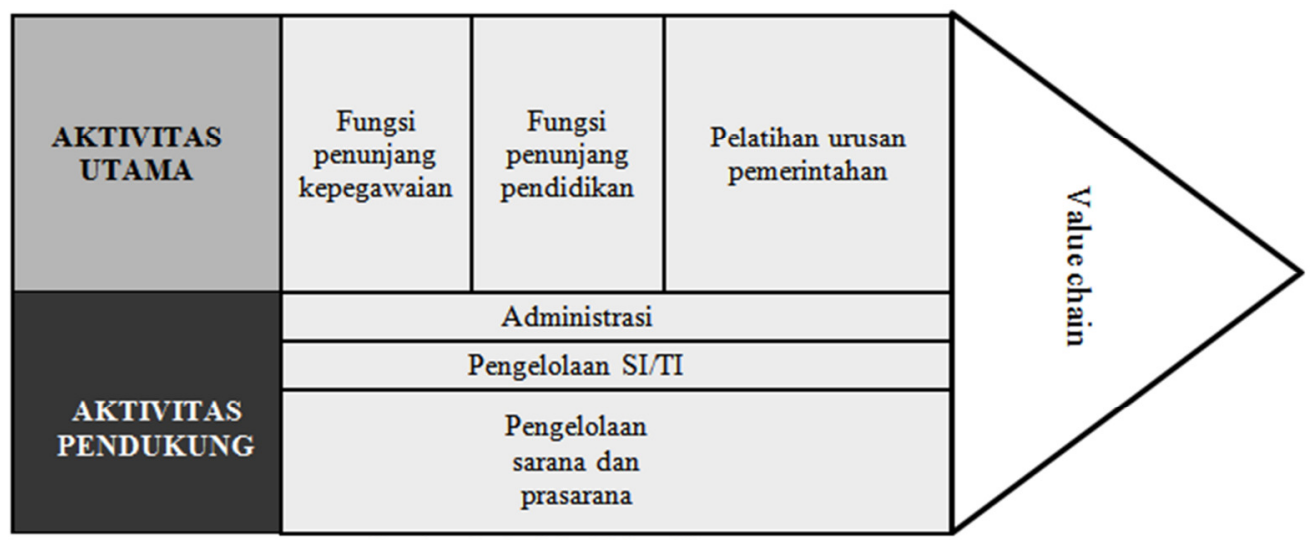

Gambar 3. Anlisis Value Chain

Setelah dilakukan pemetaan dapat disimpulkan:

1. Aktifitas utama (main activity) terdiri dari:
a. Fungsi kepegawain
b. Fungsi penunjang pendidikan
c. Pelatihan Pemerintahan

Rissanti, et., al [Perencanaan Strategi Sistem Informasi pada BKDIKLATDA Kota Salatiga Metode Ward and 
2. Aktifitas pendukung (support activity) terdiri :

a. Administrasi

b. Pengelolaan SI/TI

c. Pengelolaan sarana dan prasarana

Ada beberapa penerapan sistem informasi di BKDIKLATDA kota Salatiga secara internal. Hal ini bertujuan untuk mengetahui sejauh manakah SI/TI yang sudah di terapkan maupun di kembangkan di organisasi tersebut. Seperti pada tabel 2 di bawah ini:

Tabel 2. Penerapan SI di BKDIKLATDA

\begin{tabular}{|c|l|l|l|}
\hline No & Nama Aplikasi & Pengguna & Jenis Aplikasi \\
\hline 1 & SI CUTE & Admin & WEB \\
\hline 2 & SI ABSENSI & Admin & Dekstop \\
\hline 3 & SIMPEG & Umum & Web \\
\hline 4 & E KINERJA & Umum & Web \\
\hline
\end{tabular}

Pada tabel 2 menjelaskan penerapan SI/TI pada BKDIKLATDA kota Salatiga yang sudah di terapkan yaitu:

1. Sistem informasi cuti elektronik (si cute) adalah aplikasi berbasis web yang di kelola oleh admin BKDIKLATDA kota Salatiga pada bidang pembinaan dan mutasi. Aplikasi ini dapat di akses oleh seluruh PNS kota Salatiga. Untuk pegawai yang akan mengajukan cuti dapat mendaftar di website ini. Semua informasi mengenai cuti dapat di akes oleh user di dalam aplikasi ini. Aplikasi si cute dapat di akses dimana pun dan kapan pun.

2. Sistem informasi absensi yaitu aplikasi yang berbasis web dan di kelola admin BKDIKLATDA kota Salatiga. Aplikasi ini bertujuan untuk mempermudah admin merekap data absen PNS kota Salatiga pada setiap bulan.

3. Sistem informasi kepegawaian(Simpeg) adalah aplikasi berbasis web yang digunakan oleh seluruh PNS guna untuk mengetahui semua data informasi kepegawain.

4. Aplikasi e kinerja. Aplikasi berbasis web ini bertujuan untuk mencatat kinerja harian kepegawaian dan di akses seluruh pegawai.

\subsection{Usulan sistem informasi}

Analisis yang dilakukan menghasilkan sebuah usulan sistem informasi guna untuk mewujudkan strategi yang akan digunakan, sehingga peneliti menghasilkan susunan aplikasi portofolio serta dapat digunakan untuk beberapa tahun mendatang. Pada tabel 3 hasil bentuk usulan sistem informasi.

Tabel 3. Usulan Sistem Informasi

\begin{tabular}{|c|l|c|c|l|}
\hline No & $\begin{array}{c}\text { Nama Sistem } \\
\text { Informasi }\end{array}$ & Pengguna & Jenis Aplikasi & \multicolumn{1}{|c|}{ Fungsi } \\
\hline 1. & SI Arsip & Pegawai & Web & $\begin{array}{l}\text { Guna untuk pengarsipan data. } \\
\text { Supaya saat kehilangan berkas sudah } \\
\text { mempunyai arsip yang terstruktur }\end{array}$ \\
\hline 2. & SI SARPRAS & Umum & Web & $\begin{array}{l}\text { SI SARPRAS bertujuan untuk } \\
\text { peminjaman alat dan ruangan di } \\
\text { BKDIKLATDA kota Salatiga. }\end{array}$ \\
\hline 3. & SI E-TTD & Admin & Web & $\begin{array}{l}\text { Mengurangi penggunaan kertas serta } \\
\text { percepat pekerjaan }\end{array}$ \\
\hline
\end{tabular}

Rissanti, et., al [Perencanaan Strategi Sistem Informasi pada BKDIKLATDA Kota Salatiga Metode Ward and 


\subsection{Portololio Aplikasi}

Tabel 4. Portofolio Aplikasi

\begin{tabular}{|c|c|}
\hline Strategic & High Potential \\
\hline $\begin{array}{l}\text { 1. SI arsip } \\
\text { 2. SI Sarpras } \\
\text { 3. SI E-TTD }\end{array}$ & SI E-TTD \\
\hline $\begin{array}{l}\text { 1. Si cute } \\
\text { 2. Si absensi } \\
\text { 3. Simpeg }\end{array}$ & E-Kinerja \\
\hline Key Opperation & Support \\
\hline
\end{tabular}

Keterangan tabel 4:

1. Strategic adalah perencanaan yang memunculkan informasi yang dapat berpengaruh terhadap proses bisnis untuk nantinya.

a. SI arsip adalah untuk pengarsipan data karena sering terjadi kehilangan berkas dengan adanya SI arsip sangat membantu pencarian berkas.

b. SI sarpras bertujuan untuk peminjaman alat dan ruangan di BKDIKLATDA kota Salatiga. karena di BKDIKLATDA sering terjadi bertabrakan peminjaman ruangan.

c. SI E-TTD adalah sebuah fitur yang dapat mempemudah dan mempercepat tanda tangan karena di BKDIKLATDA masih menggunakan tanda tangan manual yang membuat proses kerja menjadi lama.

2. High Potensial adalah merupakan peningkatkan proses kerja jangka panjang. Dimana BKDIKLATDA kota Salatiga untuk proses tanda tangan masih di lakukan secara manual dengan adanya e-ttd dapat mempersingkat waktu untuk proses tanda tangan.

3. Key Opperation merupakan sistem informasi dapat memberikan kemudahan dalam operasional di BKDIKLATDA kota Salatiga. Dimana mereka menggunakan aplikasi si cute untuk pengelolaan cuti, aplikasi absensi untuk proses pengelolaan data absensi, simpeg untuk mengetahui kepegawaian dan e kinerja untuk mencatat kinerja harian pegawai.

4. Support merupakan dimana sistem informasi dapat medukung aktifitas proses bisnis di BKDIKLATDA koata Salatiga yang berupa web.

\section{KESIMPULAN}

Dari hasil penelitian dengan menggunakan metode Ward and Peppard pada BKDIKLATDA kota Salatiga menghasilkan kesimpulan bahwa pengelolaan data verifikasi cuti perlu dikembangkan lagi dan untuk proses absensi perlu di perbarui menggunakan aplikasi absensi berbasis mobile karena sering terjadi kerusakan mesin fingerprint dan meningkatkan pengelolaan kepegawaian yang kompeten dan kompetitif. Sehingga dapat menunjang aktifitas utama dan pendukung di BKDIKLATDA kota Salatiga. Solusi sistem informasi dapat di petakan pada aplikasi portofolio yang bisa di terapkan untuk nantinya.

\section{SARAN}

Saran untuk kedepan di harapkan peneliti dapat memakai metode yang lebih luas karena pada penelitian kali ini hanya berpusat pada perencanaan strategi sistem informasi dan peneliti bisa mengimplementasikan dan mengembangkan pada penelitian ini.

Rissanti, et., al [Perencanaan Strategi Sistem Informasi pada BKDIKLATDA Kota Salatiga Metode Ward and 


\section{DAFTAR PUSTAKA}

[1] A. Wiyono and A. F. Wijaya, 2020, "Perencanaan Strategis Sistem Informasi Di PT. Telekomunikasi Indonesia, Tbk WITEL Semarang Menggunakan Ward and Peppard," J. Bina Komput., Vol. 2, No. 1, pp. 23-32, doi: 10.33557/binakomputer.v2i1.797.

[2] A. F. Wijaya and V. D. R. Damara, 2020, "Perencanaan Strategis SI/TI pada Document Management Menggunakan Ward and Peppard (Studi Kasus: PT. Visionet Data International)," J. Bina Komput., Vol. 2, No. 1, pp. 33-43, doi: 10.33557/binakomputer.v2i1.796.

[3] Akadun, 2007, "Good Governance Dalam Otonomi Daerah," Sosiohumaniora J. Soc. Sci. Humanit., Vol. 9, No. 1, pp. 37-47, [Online]. Available: http://jurnal.unpad.ac.id/sosiohumaniora/article/view/5375.

[4] Y. Utami, A. Nugroho, and A. F. Wijaya, 2018, "Perencanaan Strategis Sistem Informasi dan Teknologi Informasi pada Dinas Perindustrian dan Tenaga Kerja Kota Salatiga," J. Teknol. Inf. dan Ilmu Komput., Vol. 5, No. 3, p. 253, doi: 10.25126/jtiik.201853655.

[5] A. Lah, Y. Rahardja, and M. N. N. Sitokdana, 2019, "Perencanaan Strategis Sistem Informasi Menggunakan Metode Ward and Peppard pada PT. Serasi Autoraya," Sebatik, Vol. 23, No. 1, pp. 185-191, doi: 10.46984/sebatik.v23i1.467.

[6] P. N. Basuki and H. P. Chernovita, "Perencanaan Strategis Sistem Informasi menggunakan Metode Ward and Peppard di BARENLITBANGDA Kabupaten Semarang," Vol. 09, No. 01, pp. 1-14, 2019.

[7] I. Nur Arifani and A. Darmawan, 2016. "Kependidikan (Studi Kasus: pada Disdikbudpora Metro), ” Vol. 02,

[8] D. Gazella, E. Darwiyanto, and G. A. A. Wisudiawan, "Perencanaan Strategis Sistem Informasi pada Industri Manufaktur Menggunakan Metode Ward and Peppard (Studi Kasus: PT. Fin Komodo Teknologi)," e-Proceedings Eng., Vol. 3, No. 3, pp. 5230-5237, 2016, [Online]. Available: http://libraryeproceeding.telkomuniversity.ac.id/index.php/engineering/article/view/3247.

[9] P. Strategis et al., "Metode Ward and Peppard (Studi Kasus: Dinas Kependudukan dan Pencatatan Sipil Kota Tomohon)," Perenc. Strateg. Sist. Inf. Menggunakan Metod. Ward Peppard (Studi Kasus Dinas Kependud. dan Pencatatan Sipil Kota Tomohon), Vol., No., pp. 604-610.

[10] S. Kasus, C. V Grafika, P. Mitra, M. F. Johannis, A. R. Tanaamah, and P. Chernovita, “Metode Ward and Peppard," pp. 611-618.

[11] Anharudin, 2015. "Perencanaan Strategis Sistem Informasi Untuk Meningkatkan Pelayanan Menggunakan Metode Ward and Peppard (Studi Kasus: PT Pos Indonesia Cilegon - Banten)," J. PROSISKO, Vol. 2, No. 2, pp. 1-4, 